\title{
EVOLUÇÃO POLIGENÉTICA DAS BAUXITAS DO DISTRITO DE PARAGOMINAS- AÇAILÂNDIA (ESTADOS DO PARÁ E MARANHÃO)
}

\author{
BASILE KOTSCHOUBEY* e WERNER TRUCKENBRODT*
}

\begin{abstract}
The aluminous laterite surfacing the area of Açailândia-Paragominas (Easterr. Amazônia) displays a profile characterized by ferruginous lateritic crust underlain by alumina-rich bauxite. The lithology is of a complex origin marked by multiple mechanical reworking and mobilization of $\mathrm{Al}$ and $\mathrm{Fe}$. Five successive stages in the evolution history are recognized: initial laterization, formation of a iron-aluminious "hard cap" and its partial reworking, first and main phase of "gibbsitization" of the hard cap, second phase reworking of laterite and its deposition as pseudo-pisolites and second phase of "gibbsitization" affecting the upper part of laterite.

Epeirogenetic movements affecting the rate of erosion and drainage with superimposed climatic changes were important factors controlling the pedogenesis. Based on analogy with Surinam occurrences and because the studied profiles are underlain by Upper Cretaceous sediments, an early tertiary age is proposed for the Eastern Amazônia bauxitic laterites.
\end{abstract}

INTRODUÇÃo As bauxitas da Amazônia brasileira foram estudadas por vários autores (Towse e Vinson, 1959; Wolf, 1972; Wolf e Șilva, 1973; Greig, 1977; Dennen e Norton, 1977; Assad, 1978; Grubb, 1979; e outros), que estabeleceram perfis-tipo das principais áreas bauxitiferas e definiram as linhas gerais dos aspectos mineralógicos, estruturais e texturais dessas lateritas aluminosas.

A sequêencia bauxítica foi interpretada como uma cobertura residual de tipo blanket formada in situ sobre e a partir de rochas da Formação Barreiras do Terciário Superior. Mais recentemente, Grubb (1979) comparou as bauxitas da Amazônia brasileira com as das Guianas e outras regizes do mundo. Procurando dar um aspecto mais evolutivo à gênese da laterita aluminosa, este autor ressaltou a importância das migrações de $\mathrm{Al}$ e Fe, e dos retrabalhamentos mecânicos.

A geoquímica dos elementos principais e traços foi investigada em alguns exemplos do Baixo Amazonas e da região de Paragominas (Dennen e Norton, 1977; Kronberg et al., 1979) na tentativa de determinar melhor a distribuição e o comportamento dos elementos durante a formação da sequeência laterito-bauxítica.

$O$ reconhecimento de mudanças faciológicas laterais na seqüência laterito-bauxítica da região de Paragominas e a existência freqüente de dois horizontes bauxíticos distintos, exibindo um enriquecimento geral em gibbsita de sul para norte, levaram os autores deste trabalho a reconsiderar os aspectos regionais e genéticos da cobertura laterítica aluminosa dentro do contexto geológico-estrutural da área e a propor um modelo evolutivo para essas bauxitas.

As investigaçð̃es na região de Açailândia-Paragominas foram favorecidas pelo fácil acesso e pela existência de excelentes afloramentos ao longo da rodovia BR-010 (Belém-Brasília) e na Serra de Miltônia, situada a cerca de $40 \mathrm{~km}$ a sudoeste de Paragominas. Foi estudada uma estreita faixa de direção geral norte-sul com cerca de $300 \mathrm{~km}$ de extensão, de Imperatriz aos arredores de Paragominas (Fig. 1).

O trabalho consistiu em observações de campo, regionais e locais, descrição e amostragem de perfis tanto verticais quanto laterais na BR-010 e em áreas adjacentes (Fig. 2). O material coletado foi objeto de estudos em laboratório por microscopia óptica e difração de raios X.

GEOMORFOLOGIA DA ÁREA A região bauxitífera investigada é uma vasta área sobrelevada de altitude variável entre 200 e $350 \mathrm{~m}$. Ela foi nivelada pelo aplainamento plio-pleistocênico e cortada por vales largos e profundos. Destacam-se amplos platôs dissecados dominando as áreas mais baixas, de relevo moderadamente ondulado. Certos platôs de extensão menor encontram-se isolados em verdadeiros testemunhos nas áreas afetadas por uma erosão particularmente intensa.

Um leve mas constante declive afeta a superfície aplainada dos platôs de sul para norte da região. $\mathrm{Na}$ área de Imperatriz-Açailândia encontram-se as maiores elevações sob a forma de morros isolados e o declive regional é mais acentuado (Sombroek, 1966).

GEOLOGIA REGIONAL Evolução tectônica e estratigráfica A região estudada foi até o Cretáceo Superior ligada à Bacia do Parnaíba, da qual constituía a parte mais setentrional, sofrendo um soerguimento progressivo até se depositarem sedimentos tipicamente continentais. A passagem do Cretáceo ao Terciário Inferior foi provavelmente marcada por um soerguimento notável, comparável ao movimento que afetou na mesma época o Escudo das Guianas (Krook, 1979). Seguiu-se um longo período de denudação que resultou num aplainamento da região em condiçðes de notável estabilidade tectônica.

* Núcleo de Ciências Geofísicas e Geológicas (NCGG) da Universidade Federal do Pará, Belém, PA, Brasil. Bolsistas do Conselho Nacional de Desenvolvimerío Científico e Tecnológico (CNPq) 


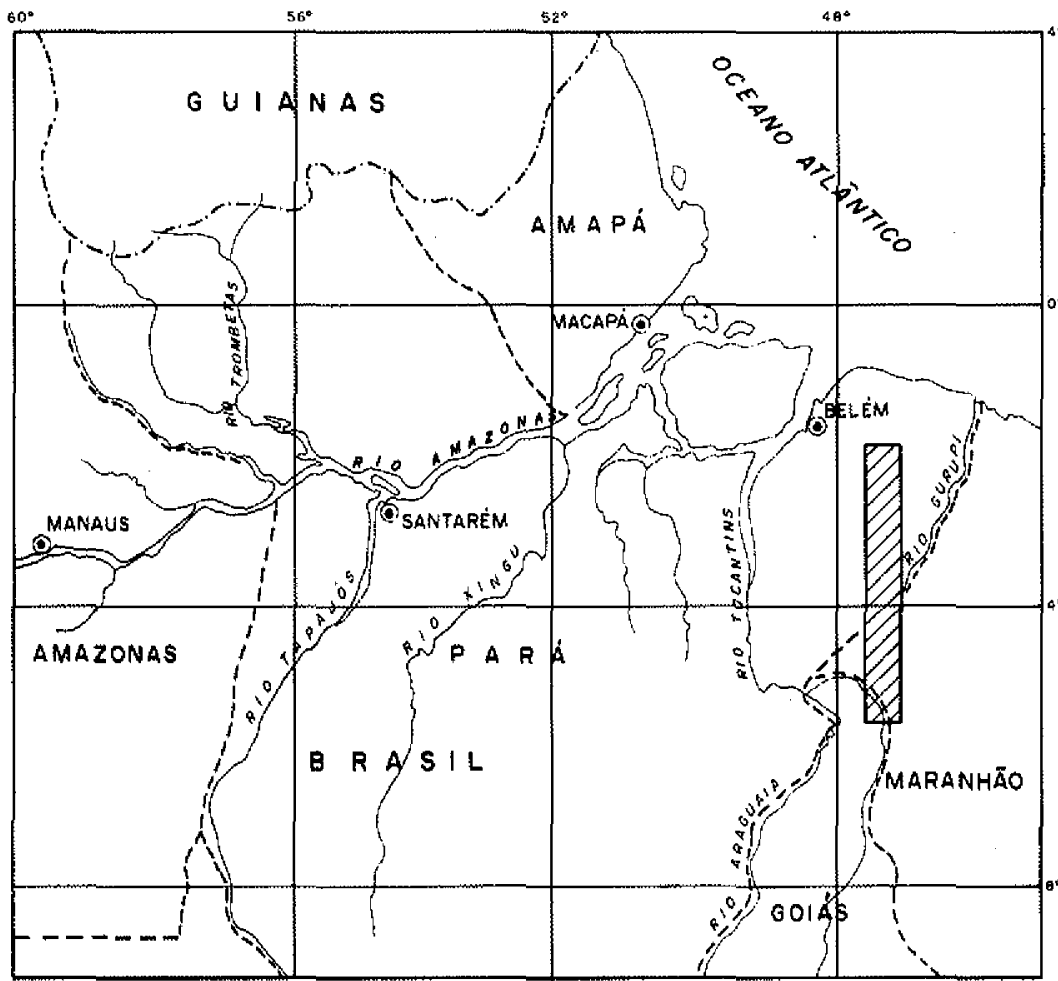

Figura 1 - Localizaça da região bauxitifera estudada, distrito de Paragominas-Açailândia

\section{LEGENDA}

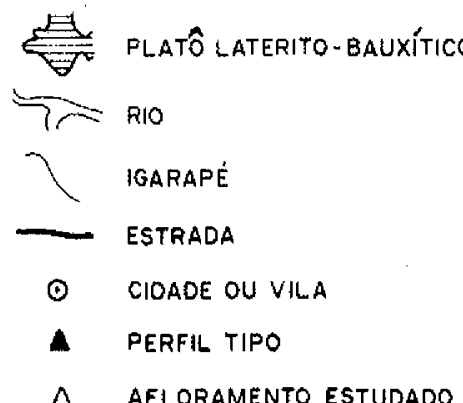

Figura 2 - Mapa de localizaça dos principais afloramentos estudados da sequéncia laterito-bauxitica entre Imperatriz e Paragominas

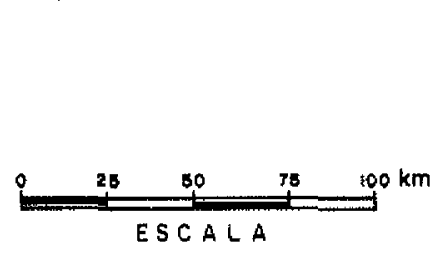

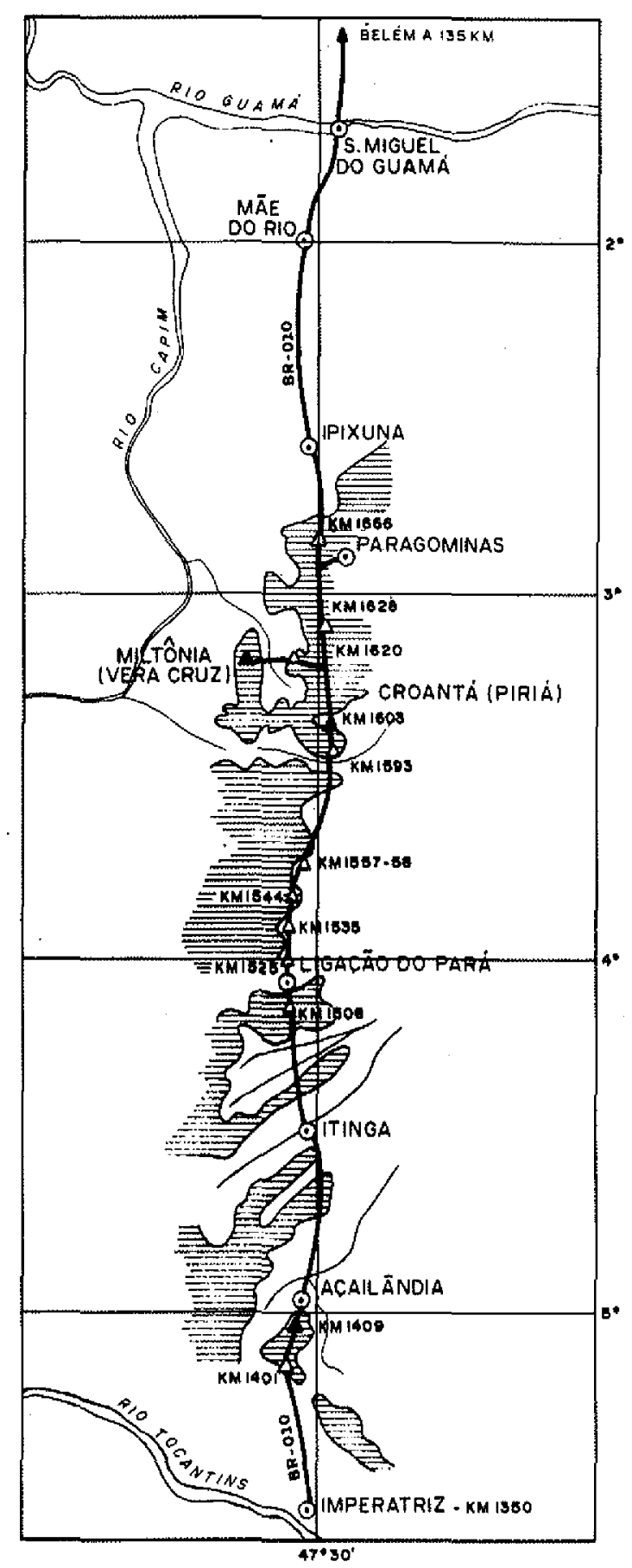

De acordo com o esquema de evolução tectônica exposto acima, a estratigrafia regional é representada essencialmente pelos sedimentos continentais que pertencem à Formação Itapecuru do Cretáceo Superior e são constituídos de arenitos cauliníticos finos com níveis argilosos e conglomeráticos. No norte da área, na região de Paragominas, observam-se sedimentos finos de fácies algo diferente dos anteriores, atribuidos à Formação Ipixuna (Francisco et al., 1971). As Formações Barreiras e Pirabas, do Terciário Superior, ocorrem bem mais ao norte, nas proximidades de Mãe do Rio (Ferreira et al., 1981).

$\mathrm{Na}$ região investigada, a seqüência laterito-bauxítica situa-se em cima da Formaçăo Itapecuru e, em sua parte setentrional, em cima dos sedimentos I pixuna. Ela é invariavelmente recoberta pela Argila de Belterra. Esta se apresenta sob forma de um pacote argiloso extremamente no aprofundamento da rede de drenagem e na formação de vários terraços fluviais. 
PERFIL ACAILANNDIA Km 1409

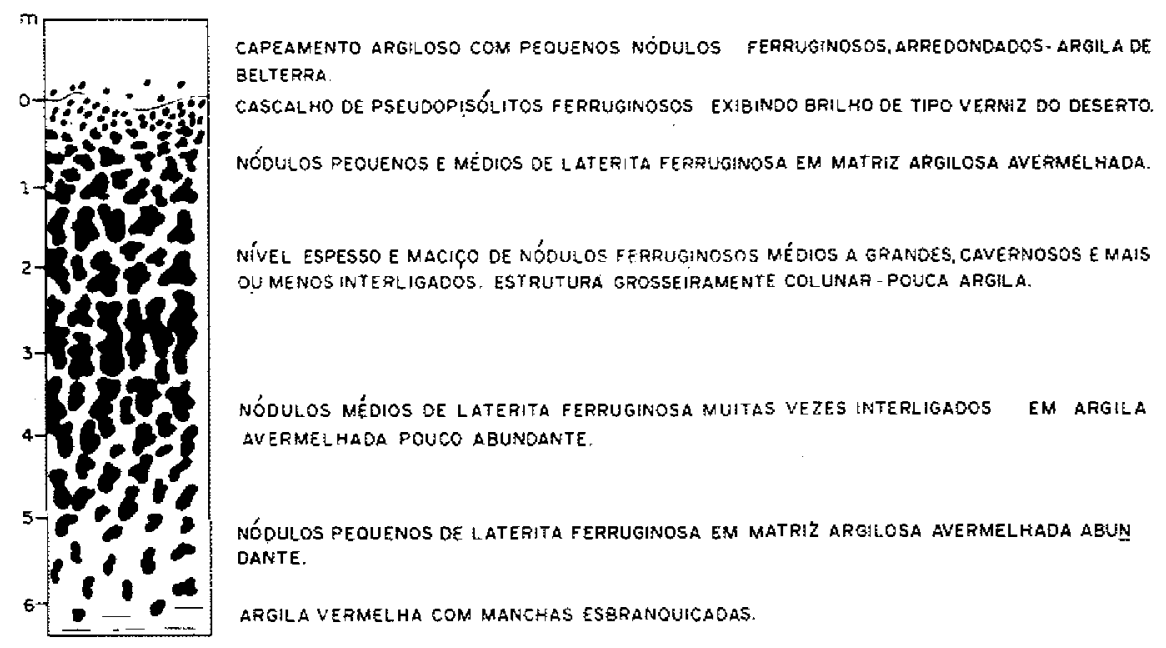

PERFIL LIGACÃO DO PARÁ km 1508

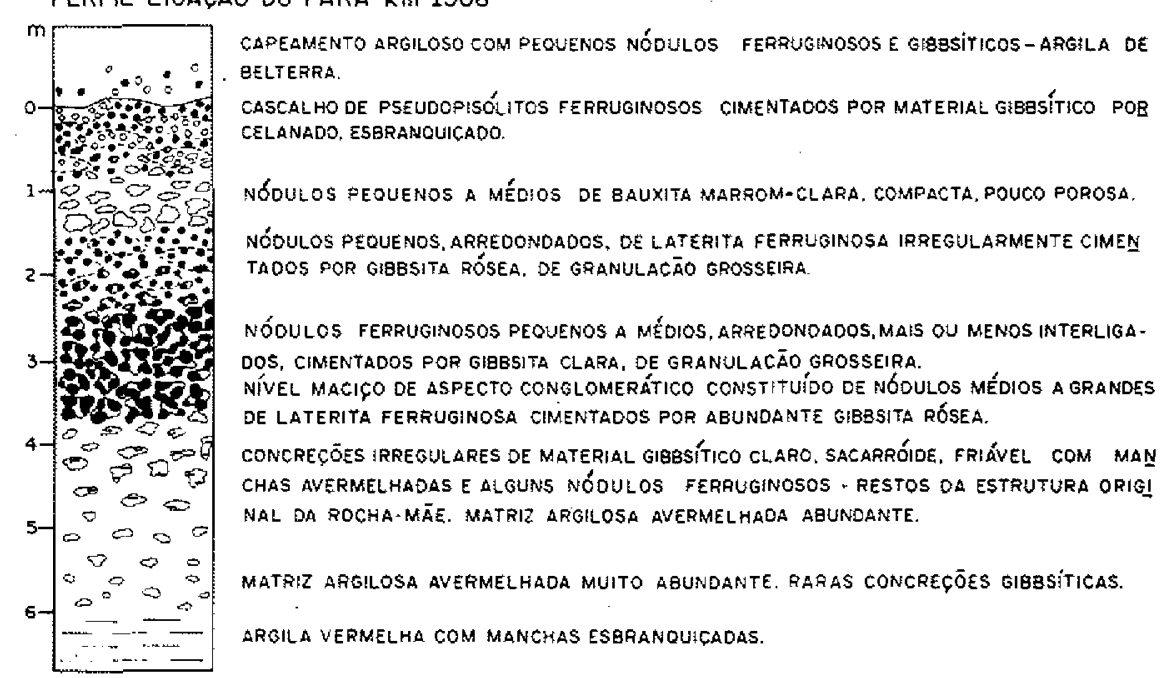

PERFIL CROANTÁ (PIRIÁ) Km I6OS

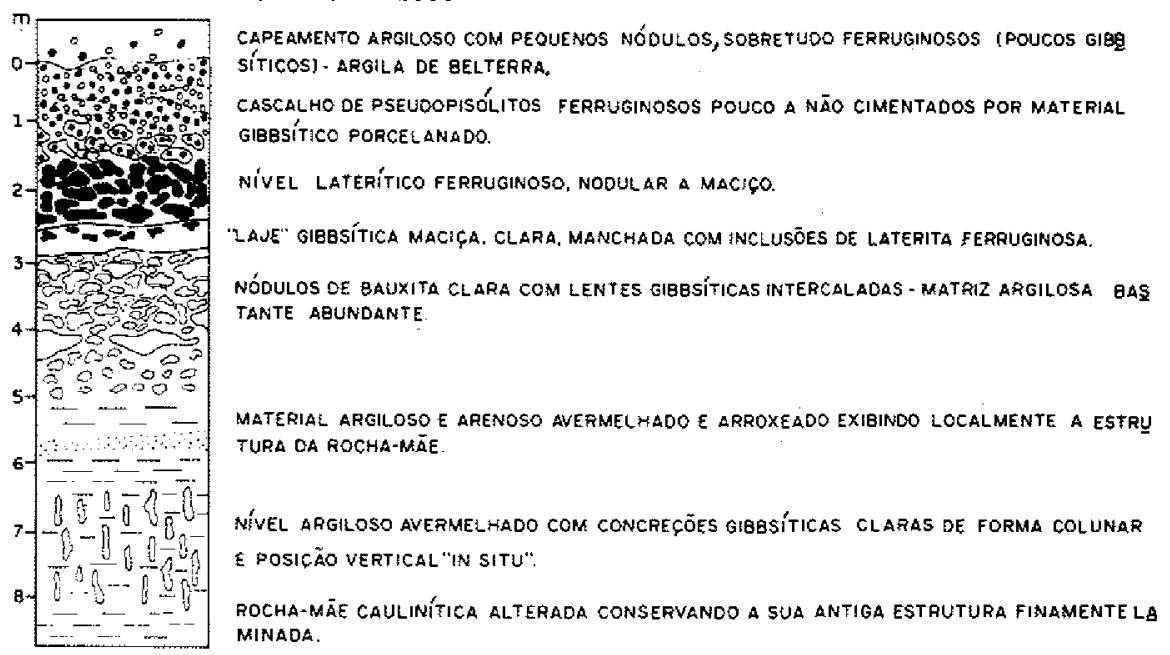

PERFIL MILTÔNIA TB

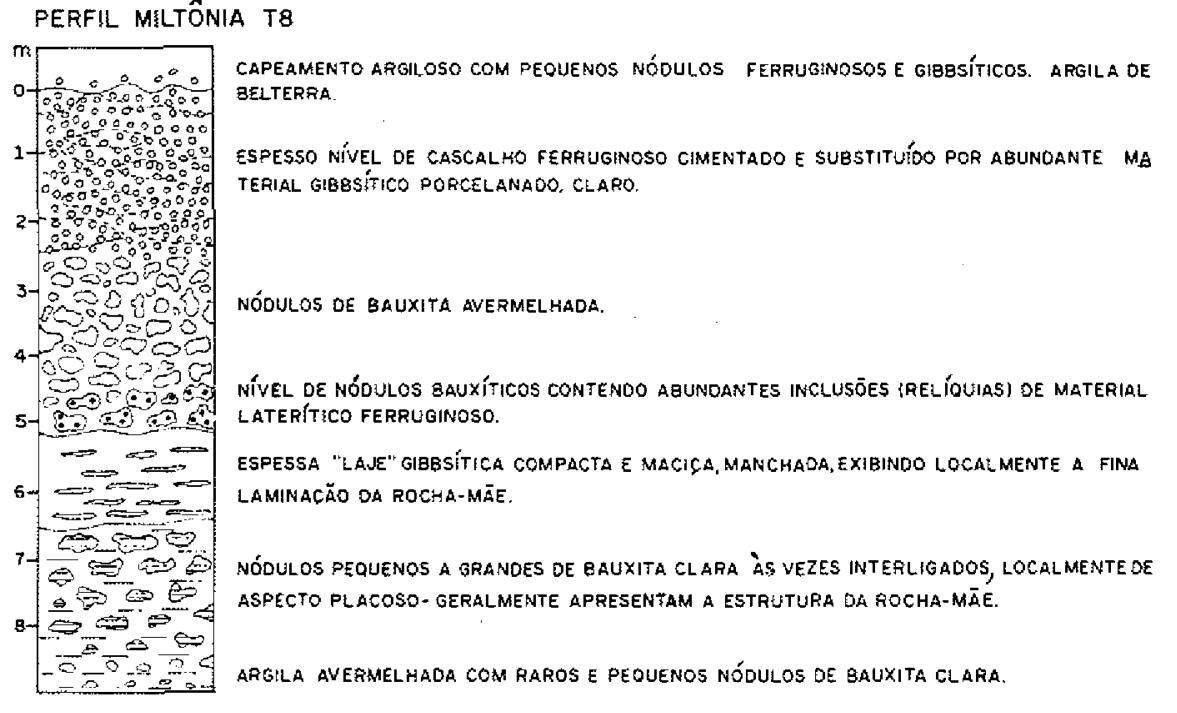


homogêneo, não exibindo estruturas e alcancando até 20 m de espessura (Truckenbrodt e Kotschoubey, 1980).

Sequiência laterito-bauxítica A seqựencia lateritobauxítica ocorre na parte superior dos platôs. Devido ao recobrimento pela Argila de Belterra e aos efeitos da erosăo, năo existem feiçôes morfológicas permitindo visualizar claramente a topografia da superfície da crosta ferro-aluminosa. Ela parece, entretanto, ser bastante ondulada.

Dos perfis estudados, quatro, de fácies diferentes, foram selecionados (Fig. $3 a$ e $3 b$ ) para servir de referência aos diferentes estágios de evolução laterito-bauxítica, permitindo estabelecer um esquema evolutivo.

A partir dos dados obtidos, foi determinado um perfil ideal sintetizando as principais variaçōes verticais e laterais (Fig. 4).

Foram definidas várias zonas, distinguindo-se de baixo para cima:

1. A rocha-matriz alterada, constituída de arenitos finos cauliníticos intercalados com horizontes sílticos e argilosos. Certos niveis apresentam um enriquecimento em mica branca. Nos 4 a $5 \mathrm{~m}$ superiores, esses sedimentos intemperizados contêm um pouco de gibbsita em pequenos agregados disseminados. Essa zona inferior tem coloração clara, esbranquiçada ou arroxeada e exibe uma es- tratificação original bem marcada. A espessura deste horizonte é mal definida. A passagem para a rocha-matriz é gradativa, realizando-se em 20 ou mais metros.

2. Um horizonte caulinítico de coloraçâo avermelhada, eventualmente manchada devido à presença de óxidos e hidróxidos de ferro. Essa zona contém bastante gibbsita, além de quartzo residual, e, às vezes, um pouco de mica. A argila é geralmente maciça, podendo também apresentar um aspecto fraturado. A estrutura da rocha-matriz ainda pode ser observada embora seja muitas vezes difusa. Excepcionalmente, concreçðes gibbsiticas podem ser encontradas nesse nivel. Geralmente, a espessura desse horizonte caulinítico é de 2 a $3 \mathrm{~m}$. O contato com a zona inferior é gradativo.

3. Um nivel inferior de bauxita concrecionar, friável, muito porosa, cavernosa, localmente compacta. As concreções têm formas variadas, muito irregulares com bordas difusas ou bem definidas, quando então se apresentam em nódulos arredondados ou plaquetas. Elas estão dispersas numa matriz argilosa avermelhada bastante abundante. A coloração da bauxita varia de esbranquiçada, rosa-pálida a marrom-avermelhada, de acordo com o conteúdo de óxido de ferro. Quando claras, as concreções podem conter inclusões ferruginosas irregulares escuras ou manchas avermelhadas, Este nível conserva às vezes a estrutura da rocha-mãe (Foto 1). Sua espessura média é de cerca de $2 \mathrm{~m}$.

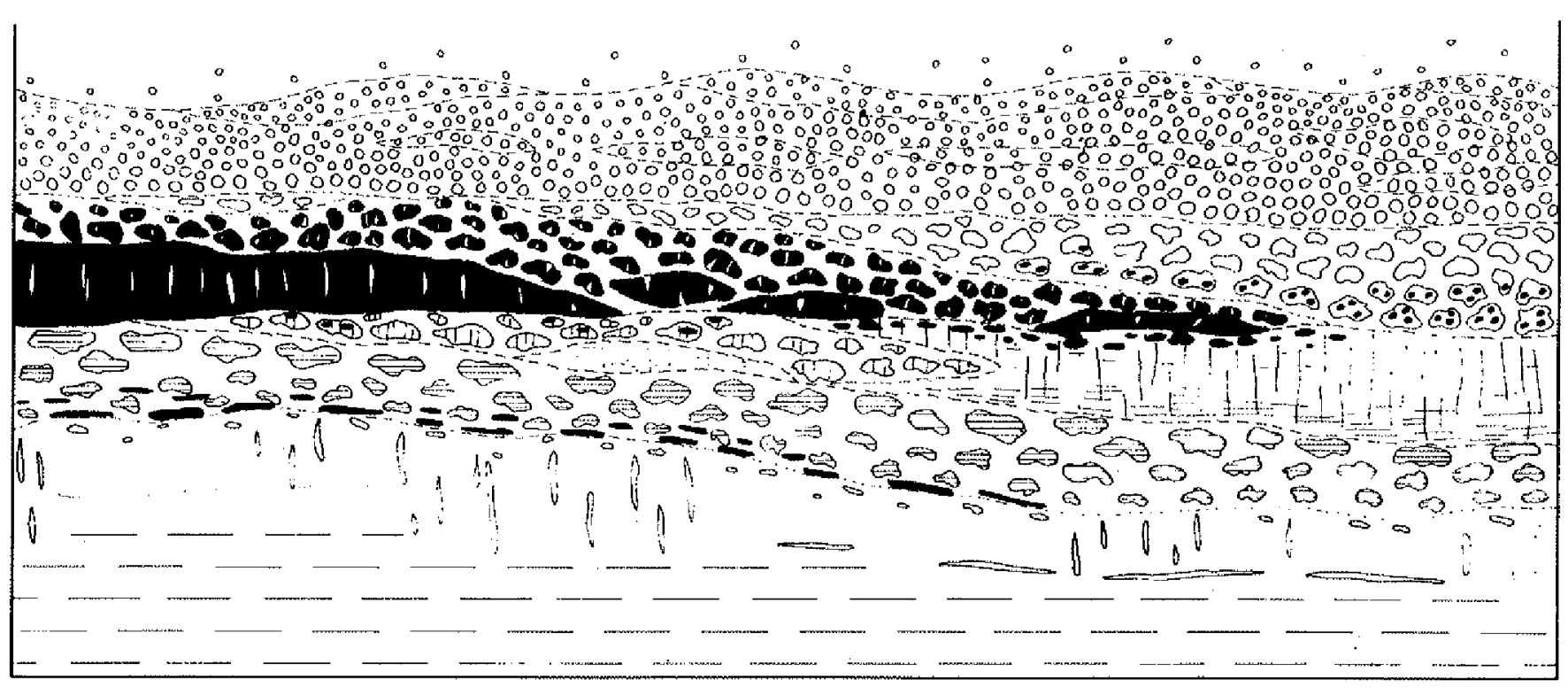

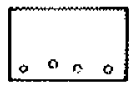

ARGILA DE BELTERRA.

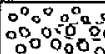
CASCALHO DE PSEUDOPISÓLITOS FERRYGINOSOS FRE-
ODENTEMENTE CIMENTADOS OU SUBSTITUIOOS POR GIBBS TA "PORCEL ANADA", ClaRA.

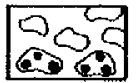

NÓOULOS E CONCREcōES BAUXÍTICOS SUPERIORES ÀS VE ZES COM INCLUSŌES (RELIOUUIAS) FERRUGINOSAS.

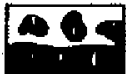

NÍVEL LATERÍTiCo FERRUGGINOSO, NODULAR A MACIÇO, HE MÁTICO E GOETITICO.
NÍVEL DE BAUXITA MACIÇA (LAJE), COMPACTA, CLARA, GE RAL.MENTE MANCHADA, COM AS VEZES NO TOPO INCLU SÖES DE LATERITA FERRUGINOSA.

NÓOULOS E CONCRECŌES BAUXÍTICOS INFERIORES, AS VEZES EM FORMA DE PLAQUETAS. CONSERVANDO PARCIALMENTE A ESTRUTURA DA ROCHA-MÄE. FREQÜENTES CONCREÇÖES FER RUGINOSAS NA BASE.

(1) $\|^{-}$HOFIZONTE ARGILOSO INFERIOR, AVERMELHADO, CONTENDO Às VEZES CONCRECOOES E DELGADOS NIVEIS GIBBSÍTICOS

ROCHA-MĀE CAULINÍTICA, ALTERADa, COM ESTRUTURA E TEXTURA ORIGINAIS CONSERVADAS. 
4. Uma zona de bauxita nodular a maciça (laje), altamente enriquecida com gibbsita de granulação grosseira com presença ou não de manchas ferruginosas. A bauxita é geralmente compacta, pouco porosa e clara (Foto 2). Raramente encontram-se relíquias da estrutura sedimentar original (Foto 3). Uma das características principais dessa zona é sua estrutura colunar grosseira. Outro fato importante é a presença, tanto dentro da laje (geralmente em sua parte superior) como nos nódulos, de inclusøes ferruginosas escuras de milimétricas a decimétricas exibindo formas variadas subarredondadas, podendo, porém mais raramente, ser angulosas (Foto 4). Nesta zona, a matriz argilosa é pouco abundante. A espessura do nível gibbsítico varia de zero a mais de $1 \mathrm{~m}$.

5. Um horizonte laterítico ferruginoso nodular, às vezes maciço em sua parte inferior, geralmente cavernoso e apresentando a estrutura grosseiramente colunar já observada no nível anterior. $O$ material goethítico e hematítico é poroso, celular, de tipo boxwork muito fino. Na maioria dos casos, ele é brechóide ou conglomerático (Fotos 5 e 6). As pequenas células são às vezes preenchidas por grãos de quartzo ou por gibbsita esbranquiçada. Certas áreas caracterizam-se pela presença de um cimento gibbsítico de granulação bastante grosseira, claro e poroso, ligando o material ferruginoso (Foto 7). A quantidade de matriz argilosa varia muito. Esse horizonte, inexistente em certas áreas, pode atingir cerca de $2 \mathrm{~m}$ de espessura. 6. Um nível superior constituído pela acumulação de pseudopisólitos (sem estrutura interna) milimétricos a centimétricos, bem arredondados, ferruginosos, cimentados ou não por gibbsita microcristalina esbranquiçada de aspecto porcelanado. Essa gibbsita chega a substituir parcial ou totalmente o cascalho ferruginoso de pseudopisólitos (Foto 8). O enriquecimento em gibbsita geralmente não é homogêneo e ocorre sob forma de lentes e nódulos, de preferência no topo do horizonte de cascaIho. Os pseudopisólitos apresentam freqüentemente uma estratificação gradacional bastante nítida. No topo do cascalho, quando não ocorreram fenômenos de cimentação e sobretudo de substituição pela gibbsita, a superfície dos pequenos seixos apresenta um brilho bem marcado, semelhante ao verniz do deserto (Foto 9). Em certas áreas, na base desta zona superior, observa-se um nível de nódulos bauxíticos compactos, pouco porosos e de coloração clara. Esse nível apresenta um limite inferior ondulado muito nítido com a acumulação de concreções e nódulos ferruginosos do horizonte sotoposto. $\mathrm{O}$ cascalho ferruginoso está quase sempre presente, alcançando até $3 \mathrm{~m}$ de espessura. Localmente, ele preenche "canais" bem visíveis no topo da seqüência.

Em determinadas áreas, como a de Açailândia ou nos quilômetros 1557 e 1544, a crosta laterítica caracteriza-se pela ausência total ou quase total de gibbsita. Isso não impede que os perfis exibam uma estrutura muito semelhante à das áreas tipicamente bauxíticas com os diferentes horizontes perfeitamente marcados. Nesses casos, entretanto, o cascalho superior às vezes coexiste com nódulos ferruginosos mais grosseiros (até $10 \mathrm{~cm}$ de comprimento) e mais angulosos.

DISCUSSÃo E INTERPRETAÇÃo A seqüência laterito-bauxítica assim descrita apresenta características particulares que diferem de um perfil bauxítico simples.
Alterações epigenéticas afetaram uma laterita inicial parcialmente bauxítica e aumentaram em muitos casos o teor original de gibbsita. São atribuidas à laterização inicial a formação da litomargem caulínitica (zona 2), a formação das concreções ferro-gibbsíticas situadas logo acima da litomargem (zona 3), assim como as manchas difusas com estruturas da rocha-matriz (Foto 3) observadas na laje e nos nódulos bauxíticos (zona 4). Por fim, os fragmentos ferro-aluminosos subarredondados a angulosos cimentados por goethita no horizonte laterítico ferruginoso (zona 5) também pertencem a essa primeira laterita. Muitas vezes, esses fragmentos estão envolvidos por um córtex amarelado, goethítico, proveniente seja da alteração centrípeta dos elementos seja da concreção em volta deles, sugerindo fragmentação e exposição à ação das águas percolantes (Hieronymus, 1973).

A primeira alteração epigenética realizou-se essencialmente na zona 4, ou seja, esse horizonte bauxítico formou-se por cimentação e substituição da primeira laterita. Os seguintes fatos sustentam esta hipótese: a existência do cimento gibbsítico róseo, de granulação grosseira, que preenche cavernas da primeira laterita, de inclusões escuras de laterita ferro-aluminosa com bordas bem definidas na bauxita maciç (laje) ou nodular da zona 4 (Foto 4) e de manchas avermelhadas de bordas geralmente difusas interpretadas como restos ou vultos de nódulos e concreções da laterita inicial.

A crosta laterítica apenas cimentada por gibbsita (Foto 7) ocorre nas seqüências menos evoluídas e corresponde estratigraficamente à bauxita nodular ou à laje (zona 4) presentes nas áreas que foram submetidas à intensa substituição da laterita ferruginosa pela gibbsita. A cimentação seria, portanto, o primeiro fenômeno à ocorrer. (quilômetro 1508), sendo seguida ou não pela substituição parcial ou completa. Os diferentes graus de substituição podem ser estimados pela razão das espessuras da bauxita nodular à maciça da zona $4 \mathrm{e}$ do horizonte ferruginoso da zona 5 . Em caso de gibbsitização intensa, a crosta ferruginosa fica reduzida e a laje torna-se mais espessa (Miltônia) à custa dessa crosta enquanto a substituição fraca resulta numa razão inversa das espessuras desses horizontes (quilômetro 1603).

Sobrepostos à crosta ferruginosa (zona 5), encontramse nódulos e pseudopisólitos hematíticos (Foto 9), em parte cimentados ou gibbsitizados (zona 6 , Foto 8). Eles exibem muitas vezes um bom arredondamento, uma certa estratiticação gradacional e preenchem canais. Este material, portanto, pode ser interpretado como fragmentos mais ou menos alóctones. A exposição em condições subáreas é marcada pelo brilho de sua superfície, um fenômeno restrito ao topo da seqüência. A cimentação e substituição dos nódulos e pseudopisólitos (zona 6) por gibbsita é o resultado de uma segunda alteração epigenética. Essa gibbsita distingue-se muito bem da gibbsita grosseira da primeira alteração por sua granulação fina, porcelanada. Mesmo em casos extremos de substituição, pequenas inclusões ferruginosas ou vultos arredondados e avermelhados dispersos nessa gibbsita porcelanada são testemunhos do cascalho ferruginoso original.

Como a comparação entre os vários afloramentos bem mostra, a bauxitização começou pela cimentação, evoluindo para a substituição centrípeta parcial ou total. A formação poligenética da bauxita, evidenciada pelas 
diferentes características expostas acima, foi controlada por retrabalhamentos mecânicos e intensas migrações tanto verticais quanto laterais do alumínio e do ferro. A importância do perfil de Açailândia, caracterizado pela ausência de gibbsita, é discutida junto ao esquema evolutivo.

\section{Comportamento do aluminio e do ferro Esses dois ele-} mentos sob sua forma iônica simples são praticamente imóveis nas condições naturais (ph 4 a 9-10) com exceção do $\mathrm{Fe}^{2+}$, que apresenta uma marcante solubilidade em ambiente ácido até cerca de ph 5,5 em condiçőes oxidantes a levemente redutoras (Britton, in Levinson, 1974). Foi mostrado por Tenyakov (1973) que, durante a laterização, a primeira forma tomada pelo alumínio retirado dos minerais da rocha-matriz é a do fon $\mathrm{AlO}(\mathrm{OH})_{2}^{-}$evoluindo rapidamente para o ín $\mathrm{Al}(\mathrm{OH})_{4}^{-}$relativamente solúvel. Sob essa forma, uma parte do aluminio é removida para fora do perfil de alteração enquanto uma outra, maior, permanece nele, sendo redistribuída de acordo com as condições locais. O íon $\mathrm{Al}(\mathrm{OH})_{4}^{-}$sofre uma evolução progressiva por polimerização até formar um complexo insolúvel que, por cristalização, dá a gibbsita. A remoção bastante rápida dos metais alcalinos e alcalinoterrosos e de grande parte da sílica cria um ambiente ácido que favorece o processo. Nessa forma, porém, especialmente quando a rocha-matriz é pobre naqueles metais, o fenômeno de gibbsitização é lento e relativamente fraco, não havendo normalmente condições para um desenvolvimento maior (Tenyakov, 1973).

A presença de cobertura vegetal densa em condiçōes tropicais úmidas permite, entretanto, a intensificação do processo. Ela sustenta uma série de fenômenos pela formação de ácidos orgânicos complexos e de seu produto de decomposição - o ácido carbônico. No mesmo tempo, o meio tende a se tornar mais redutor.

Assim, segundo Erhart (1967 e 1973), ambientes podzolizantes ou pantanosos particularmente ácidos devem ser favoráveis à mobilização de Al. O mesmo autor assinala que certas espécies vegetais são capazes de concentrar o alumínio, liberando-o em seguida após a destruição das plantas. Portanto, em condições ácidas $(\mathrm{pH}<4,5)$, o alumínio pode ser mobilizado sob forma de complexos diversos, de soluçóes coloidais ou até verdadeiras, migrando e redepositando-se quando o meio se torna menos ácido (Erhart, 1967 e 1973; Mohr et al., 1972; Tenyakov, 1973).

O ferro sofre também os efeitos do ambiente enriquecido em matéria orgânica, passando de sua forma férrica para a forma ferrosa, relativamente mais móvel, ou entrando na composição de complexos orgânicos solúveis (Millot, 1970).

Complexos ferro e ferri-silícicos também solúveis podem igualmente formar-se. Por conseguinte, sob cobertura vegetal ou acumulação de matéria orgânica e em condiçðes de clima tropical úmido, o ferro tem tendência a migrar vertical e lateralmente.

Entretanto, o grau de acidez (ph 3 a 4) e as condições fortemente oxidantes existentes perto da superfície se opzem a esca tendência, tornando o ferro férrico só parcialmente solúvel, mesmo em condiçðes tropicais, nas partes superiores do perfil de alteração (Tenyakov, 1973;
Schellmann, 1974). Isso explicaria a conservação de um horizonte altamente ferruginoso acima dos níveis aluminosos. Entretanto, a erosão, as acumulaçð̃es subseqüentes de material alóctone e as alteraçðes epigenéticas podem mascarar ou modificar a distribuição primária tanto do alumínio como do ferro no perfil.

Esquema evolutivo As bauxitas poligenéticas da região de Paragominas são o resultado de mudanças ambientais ocorridas durante sua formação. Segundo Valeton (1980), a alteração epigenética em meio laterito-bauxítico exige soerguimento ou abaixamento tectônico e/ou mudança climática. No caso considerado, embora movimentos epirogenéticos não possam ser descartados, as variações climáticas parecem ter tido o papel primordial.

O modelo genético, exposto em seguida, é uma tentativa de descrever a evolução do ambiente geológico e seus efeitos na formação da bauxita de Paragominas. Cinco fases podem ser distinguidas (Fig. 5).

1. Durante uma primeira etapa, ou seja, durante um prolongado período de estabilidade tectônica e clima úmido e quente, formou-se a laterita inicial contendo gibbsita, provavelmente em quantidades notáveis. Esse processo realizou-se com maior intensidade nas partes topograficamente mais elevadas que foram submetidas a uma lixiviação vigorosa. Foram removidos os metais alcalinos e alcalino-terrosos, e grande parte da sílica. Nas depressões, a lixiviação foi menos acentuada, levando à formação de solos lateríticos com nível de plintito.

2. Em seguida, uma mudança climática para um regime mais seco causou o desmantelamento parcial da crosta laterítica devido à diminuição da vegetação protetora. Enquanto a maior parte do material desmantelado permanecia in situ, uma porção menor teria sido transportada sob forma de debris flow para as áreas deprimidas.

3. Os fragmentos acumulados foram cimentados por material ferruginoso, sobretudo goethítico, muitas vezes com gibbsita subordinada. Finalmente, uma remobilização mais intensa do alumínio levou a uma cimentação e a uma substituição relativamente acentuada da crosta original pela gibbsita, indicando condiçôes climáticas úmidas sob cobertura vegetal densa.

4. Após esse período bauxitizante, instalou-se de novo um clima mais árido, resultando numa outra fase de retrabalhamento da crosta laterito-bauxítica. A escassez da vegetação permitiu que um volume considerável de fragmentos da crosta fosse transportado e depositado sob forma de acumulações de pequenos nódulos e pseudopisólitos. Assim, a vasta área aplainada com leve declive para norte, resultando do soerguimento regional, acabou sendo recoberta por um extenso lençol de cascalho.

5. A última fase de evolução bauxítica teve lugar num período durante o qual predominaram fenômenos químicos condicionados por um regime climático quente e úmido, e por uma cobertura vegeral exuberante. Ocorreu principalmente uma nova remobilização do alumínio que migrou tanto vertical quanto lateralmente, sobretudo na parte superior do perfil. Em primeiro lugar, a alumina preencheu os intestícios do cascalho ferruginoso (cimento porcelanado). Depois, ela substituiu parcial ou totalmente os pseudopisólitos. Entretanto, existem também áreas onde esses últimos assim como os nódulos maiores estão 

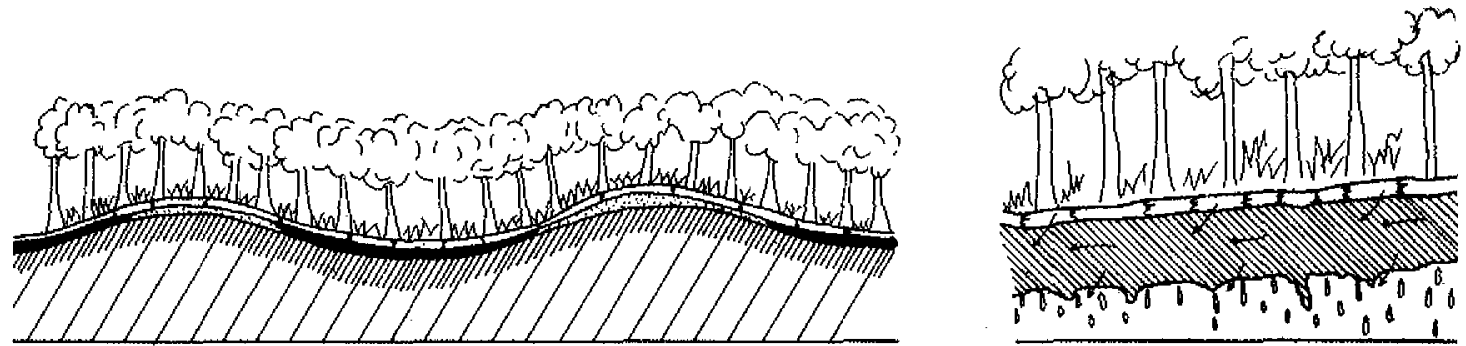

FASE INICIAL = LATERIZAGĀO
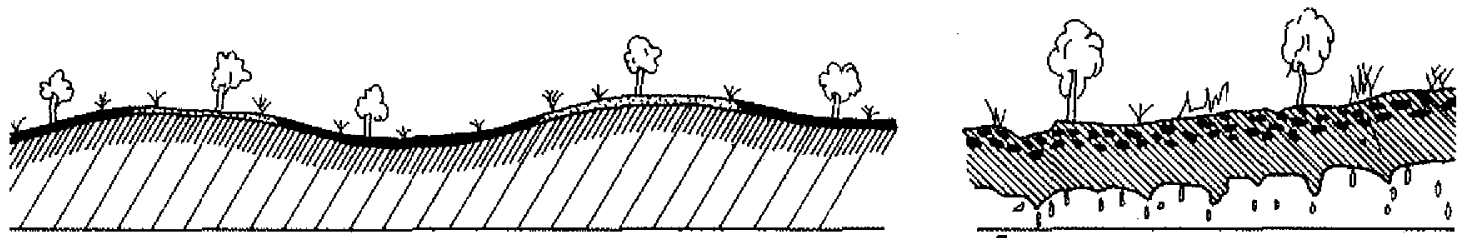

DESMANTELAMENTO PARCIAL ERECONSTITUIÇÄO DA CROSTA
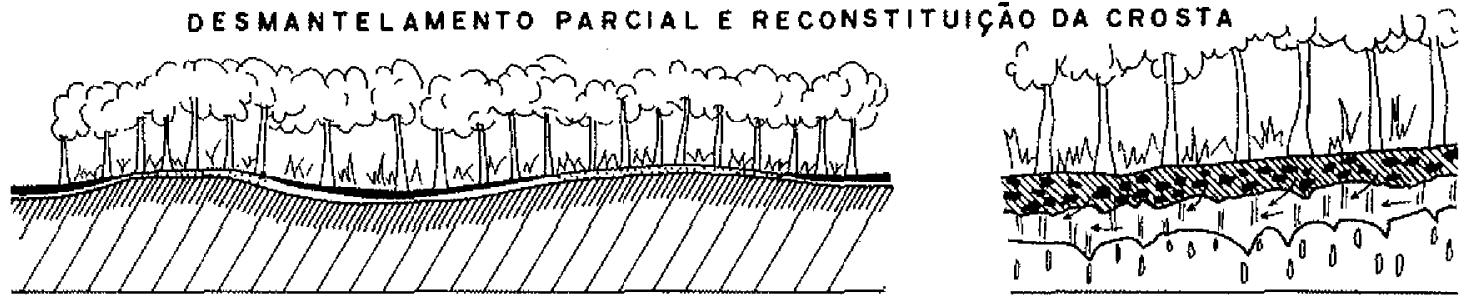

PRIMEIRA FASE DE GIBBSITIZAÇÃO

8
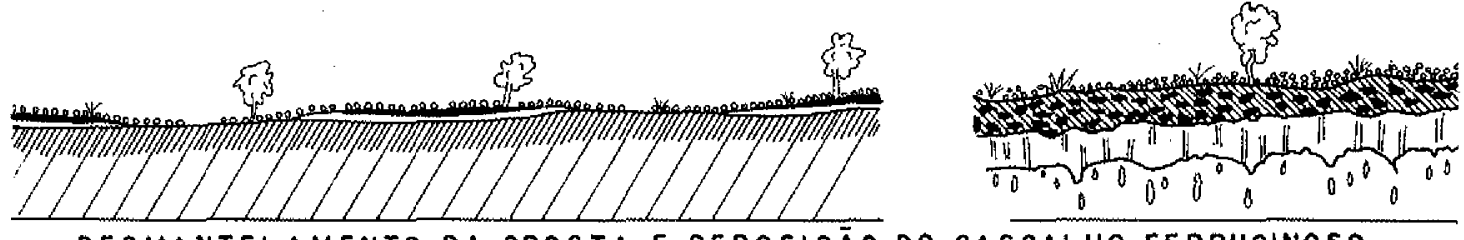

DESMANTELAMENTO DA CROSTA E DEPOSIGĀQ DO CASCALHO FERRUGINOSO cipen

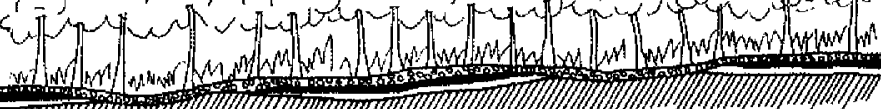
DIIIIIIIIIIIIIIIIIIIIIIIIIIIIDIIIIIIIIIIIIIIIIIIIIIIIIIIIIIIIIIIIIIIIIIIIII

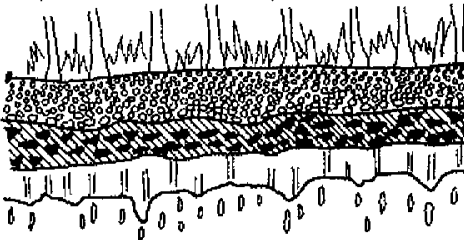
SE GUNDA FASE DE GIBBSITIZAGÃO

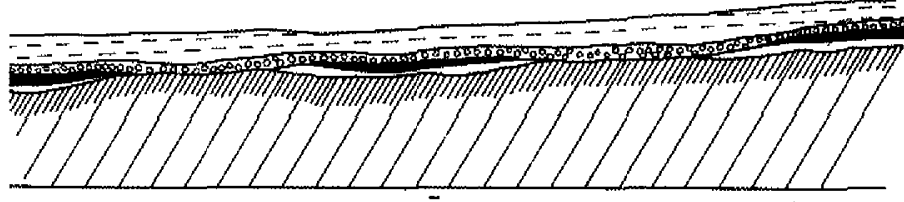

DEPOSIGÃO DO CAPEAMENTO IARGILA DE BELTERRA)
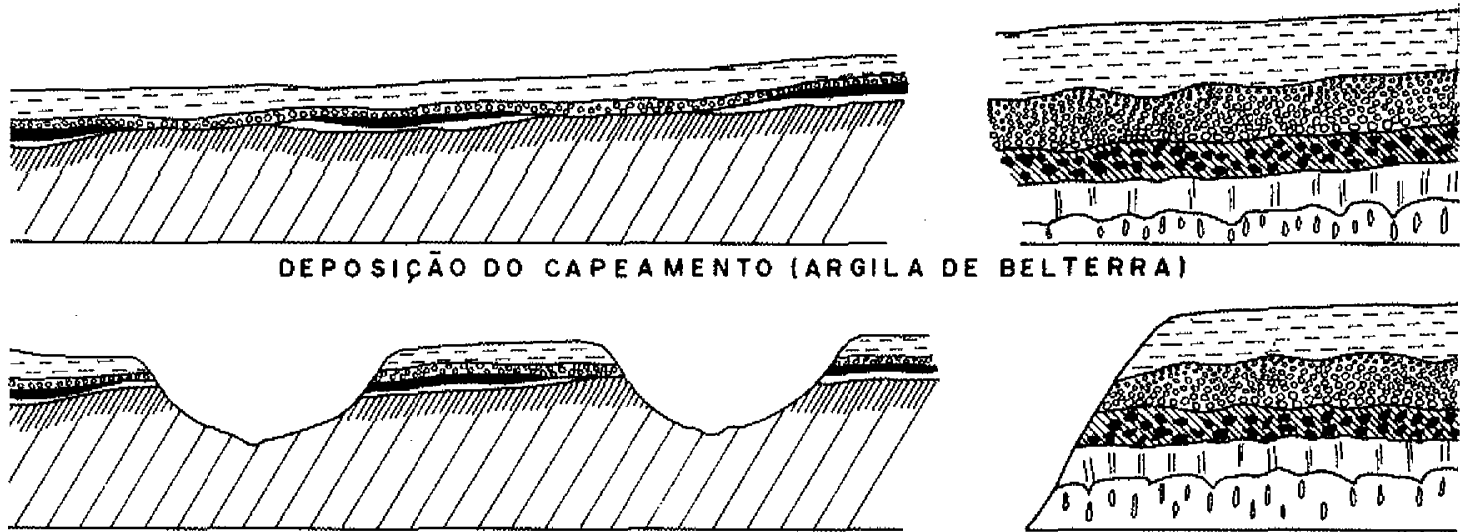

INDIVIOUALIZACĀO PÓS-PLIOCẼNICA DOS PLATÖS BAUXIYIFEROS

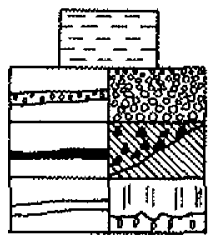

CAPEAMENTO. ARGILA DE BELTERRA.

CASCALHO FERAUGINOSO SUPERIOR.

HORIZONTE LATERITLCO FERRUGINOSO OU FERRO-ALUMINOSO

horizonte oe acumulaçáo agsoluta de al.

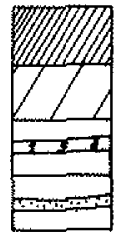

TONA CAULINITICA INFERIOR - LITOMARGEM

ROCHA-MATRIZ ALTERADA.

Figura S - Esquema interpretativo da formação poligenética da cobertura laterito-bauxitica de Paragominas-Açailândia 
quase soltos, apresentando apenas uma fraca cimentação. Isso demonstra que a cimentação e a substituição se manifestaram de maneira bastante irregular quanto a sua distribuição lateral. Nas áreas essencialmente ferruginosas, como a de Açailândia, a escassez ou ausência de gibbsita poderia ser explicada, talvez, por dois fatores: o teor muito alto em sílica da rocha-matriz, fato evidenciado pelas análises químicas, e uma drenagem desfavorável.

A bauxitização terminou com a fase 5. Posteriormente, houve deposição da Argila de Belterra (Truckenbrodt e Kotschoubey, 1980) recobrindo as áreas laterito-bauxíticas e protegendo-as da erosão. Finalmente, no PlioPleistoceno, a região sofreu um aplainamento geral (Barbosa et al., 1973; Barbosa e Pinto, 1973).

Mais recentemente, porém, um rebaixamento do nível de base provocou a individualização dos platôs bauxíticos por uma erosão intensa. A reativação dos processos erosivos foi causada seja por um novo soerguimento, seja por um rebaixamento do nivel do mar, em condições de transição de um clima relativamente seco para um regime mais úmido.

CONCLUSÃo A seqüência laterito-bauxítica tem uma origem poligenética. A laterita original foi modificada por duas fases distintas de gibbsitização. Todos os fenômenos bauxitizantes, em parte reforçados por migrações laterais de alumínio, realizaram-se durante periodos de relativa estabilidade tectônica e sob clima úmido e quente. Este foi interrompido por dois períodos mais áridos que resultaram no desmantelamento e no retrabalhamento da parte superior da crosta original. A primeira brechação ocorreu no nível da atual laje e a maioria dos fragmentos provavelmente não se deslocou. Entretanto, os pseudopisólitos do topo da seqüência

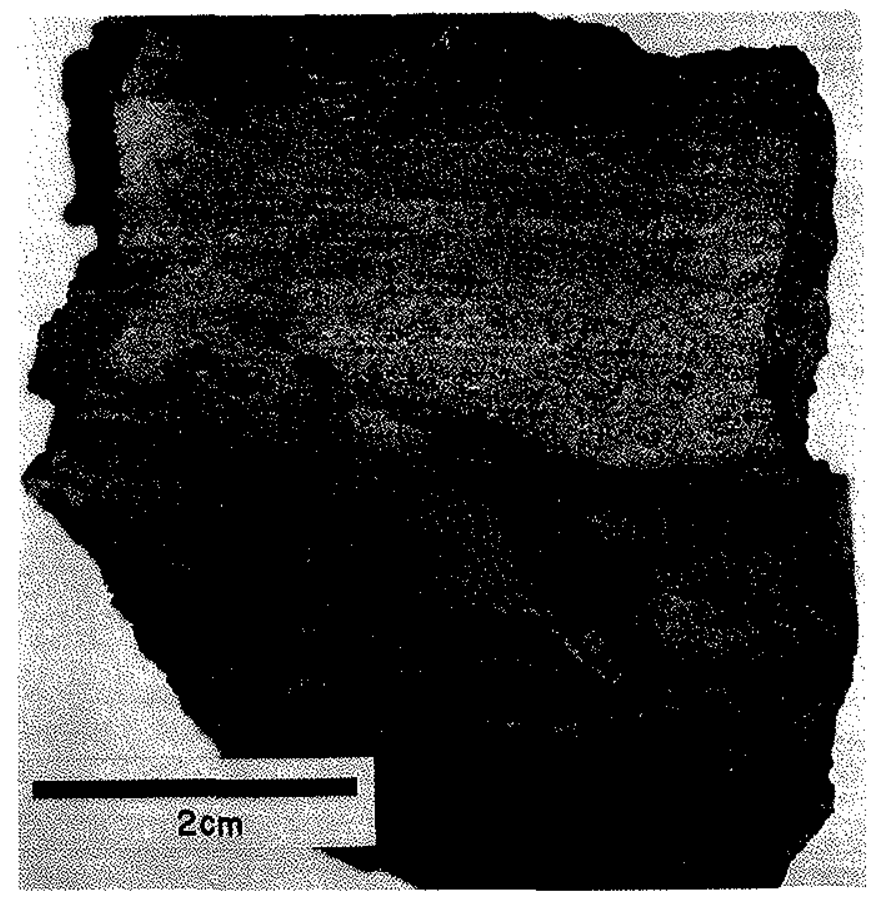

Foto I - Bauxila da base do perfil Miltônia. Embora essencialmente gibbsitico, este material conservou a estrutura finamente laminada da rocha-matriz laterito-bauxítica, ligados à segunda época seca e possivelmente a um soerguimento regional mais sensível, são interpretados como depósitos alóctones.

Evidentemente a formação poligenética da seqüência bauxitica necessitou um tempo bastante longo, pois a bauxitização é um processo lento, sobretudo quando se realiza sobre rochas sedimentares argilosas ricas em quartzo (Tenyakov, 1973; e Jepsen e Schellman, 1974). Acredita-se que, com base na comparação com as bauxitas das Guianas (Krook, 1979) e na presença do aplainamento Velhas, que afetou a Argila de Belterra no PlioPleistoceno, a gênese das bauxitas da região amazônica formadas sobre sedimentos cretácicos iniciou-se no Terciário Inferior (Eoceno) e não no Terciário Superior ou Quaternário (Wolf, 1972; Wolf e Silva, 1973; Dennen e Norton, 1977; Grubb, 1979). Essa colocação no tempo geológico parece ser mais lógica devido à ampla distribuição em escala mundial da bauxita no EocenoOligoceno (Bardossy, 1963; Valeton, 1980). Por ser um processo complexo, sujeito a condições climáticas e tectônicas variáveis, a evolução polifásica da bauxita estendeu-se possivelmente até o Terciário Superior.

Agradecimentos Agradecemos à Mineração Vera Cruz S.A. e particularmente ao geólogo B. Stilianidi Filho pela hospitalidade e o auxílio no campo, que nos permitiu realizar este trabalho. Somos gratos ao colega e amigo Raimundo Netuno N. Villas pela revisão do texto e ao pessoal técnico dos laborátorios de Sedimentologia e de Raios $\mathrm{X}$, assim como da oficina de laminação do NCGG da UFPa por sua ajuda. Expressamos também nossos agradecimentos à Finep pelo apoio financeiro a este trabalho, dentro do Projeto Integrado de Pesquisas Geológicas, Geofísicas e Geoquímicas (verba Finep/UF$\mathrm{Pa}-\mathrm{CT}-442)$.

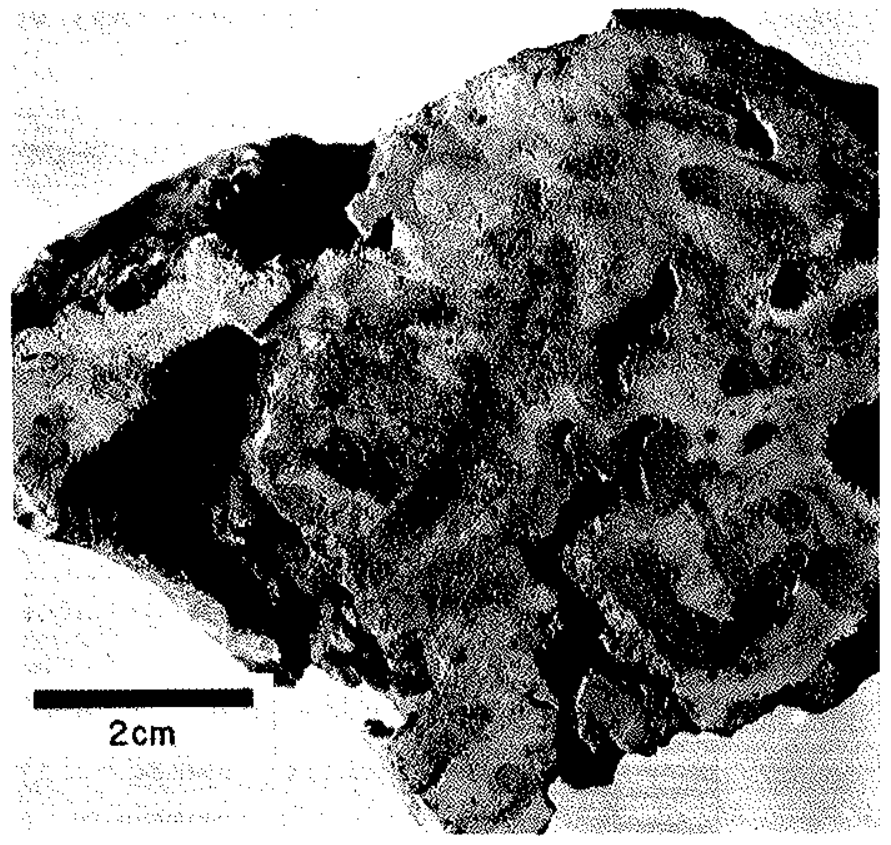

Foto 2 - Bauxita compacta bastante cavernosa, clara, proveniente da "laje"' BR-010, quilômetro 1603 


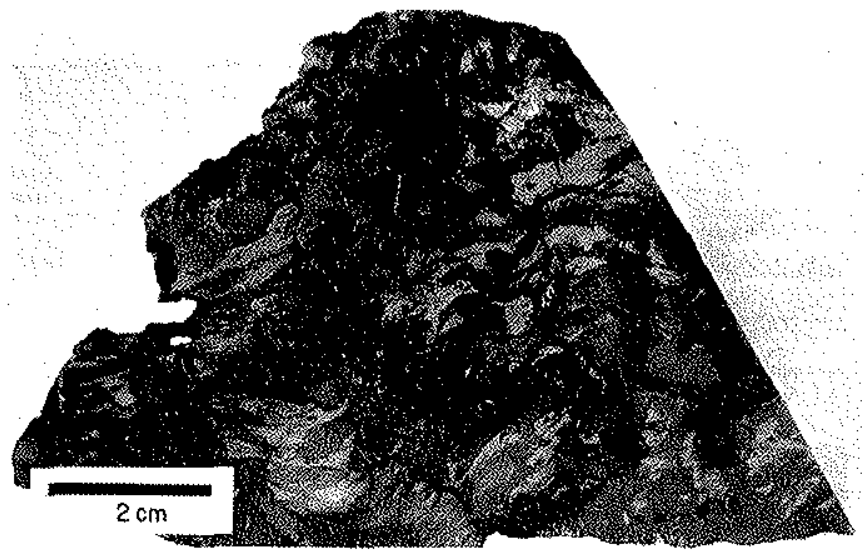

Foto 3 - Bauxita maciça, ligeiramente cavernosa, um pouco ferruginosa e manchada da "laje". Notam-se as reliquias da estrutura sedimentar original bastante perturbada da rochamatriz. Serra de Miltônia

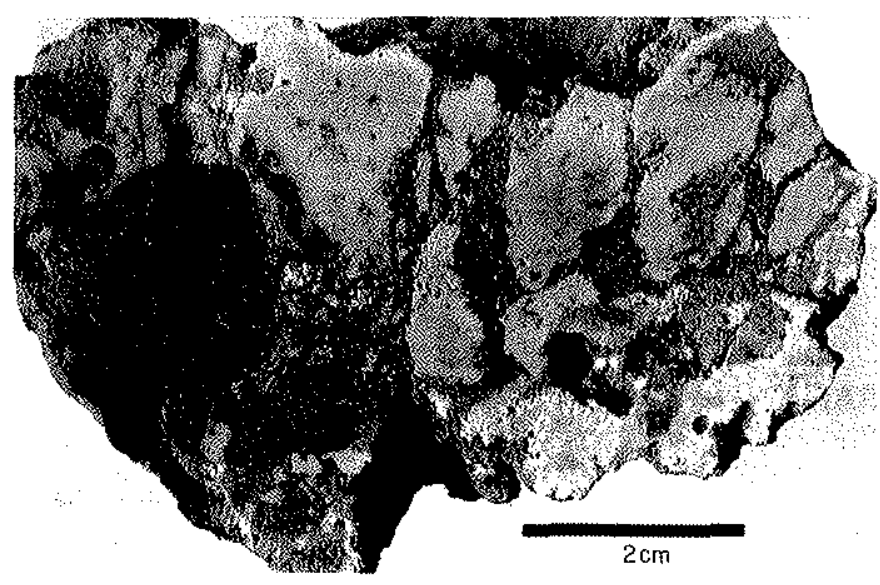

Foto 4 - Bauxita maciça da parte superior da "laje". Observase dentro do material gibbsitico manchado uma reliquia de laterita ferruginosa, escura, não substituída por hidroxido de aluminio. BR-010, quilômetro 1603

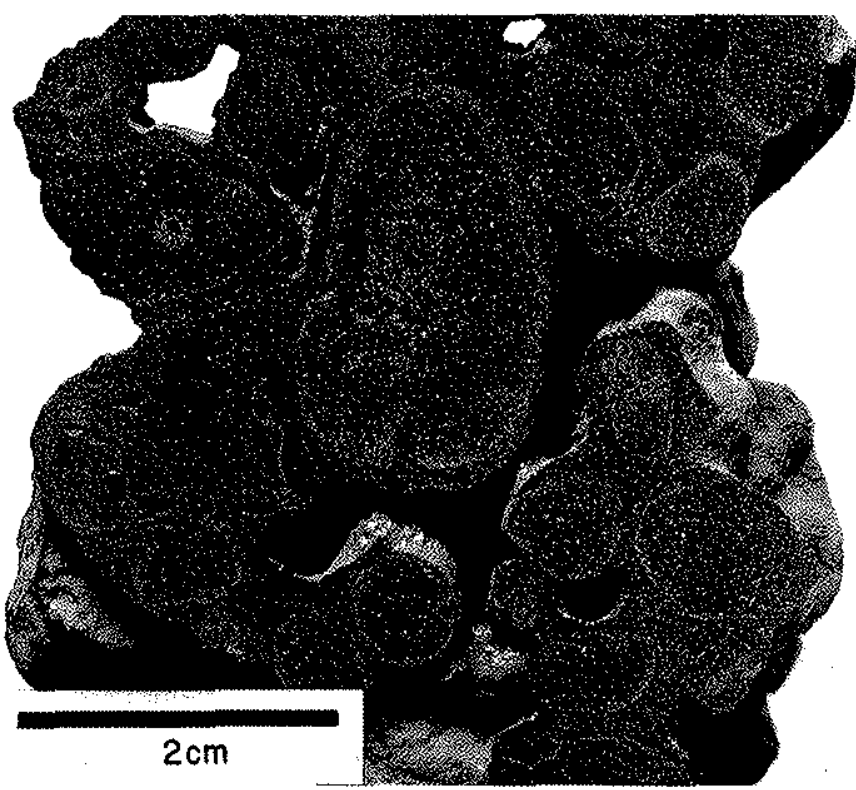

Foto 5 - Laterita ferruginosa com estrutura conglomerática. Os fragmentos arredondados sâo sublinhados por um cortex mais claro. Área de Açailandia

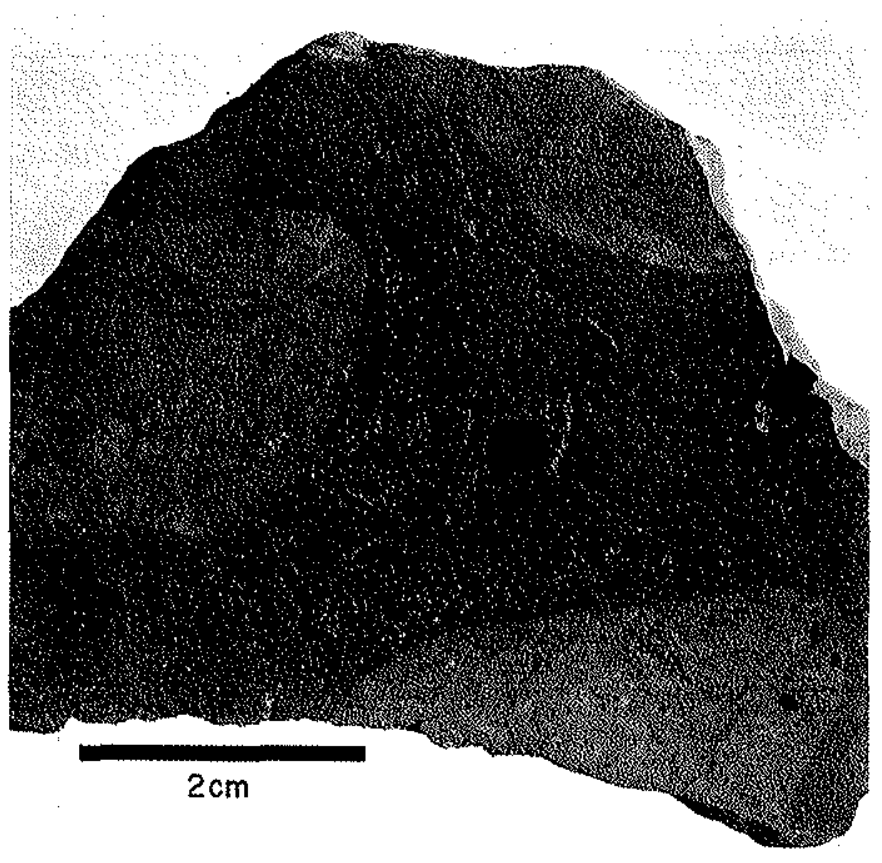

Foto 6 - Laterita ferruginosa maciça, mostrando uma estrutura conglomerática. Área de Açailândia

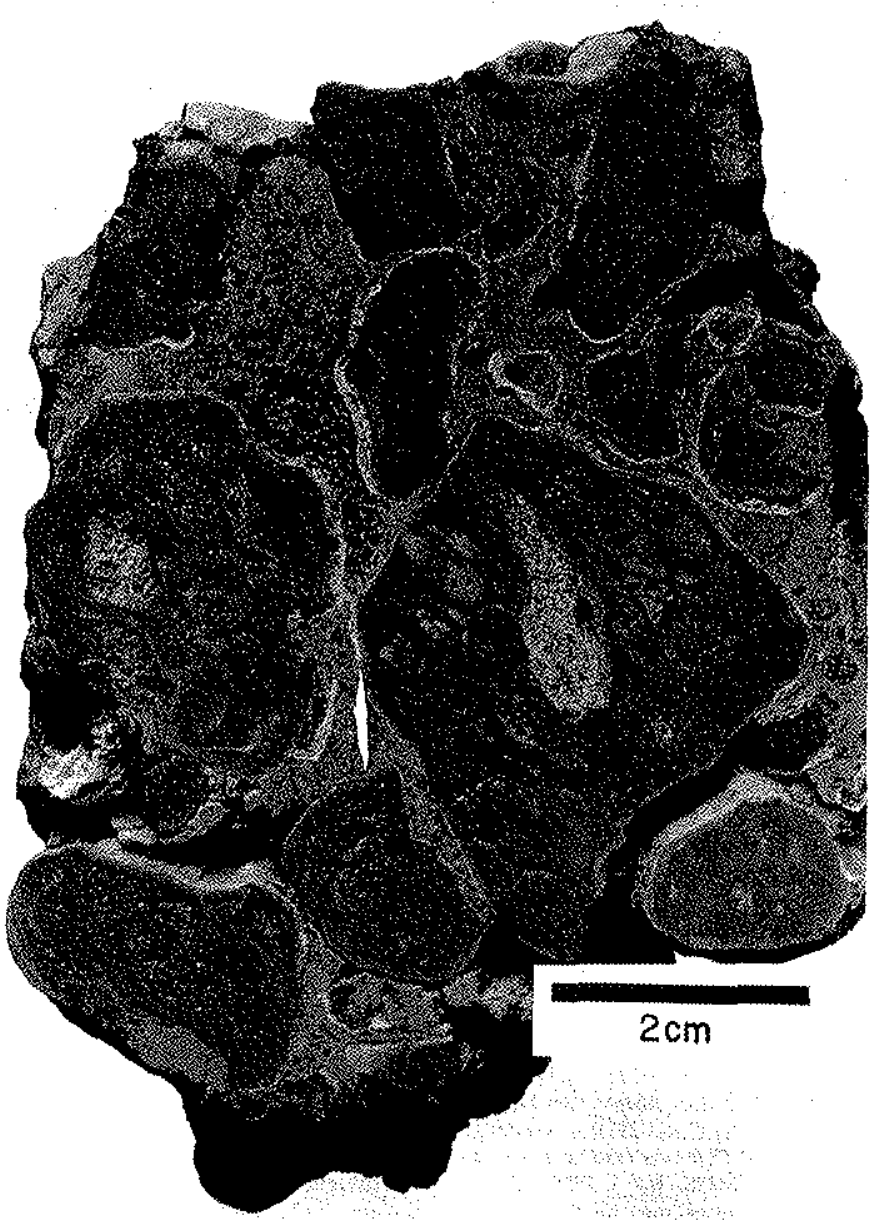

Foto 7 - Brecha laterito-bauxitica com fragmentos hematitogoethiticos cimentados por gibbsita clara. Nota-se a presença de córtex goethítico envolvendo o material ferruginoso. BR-010, quilômetro 1508 


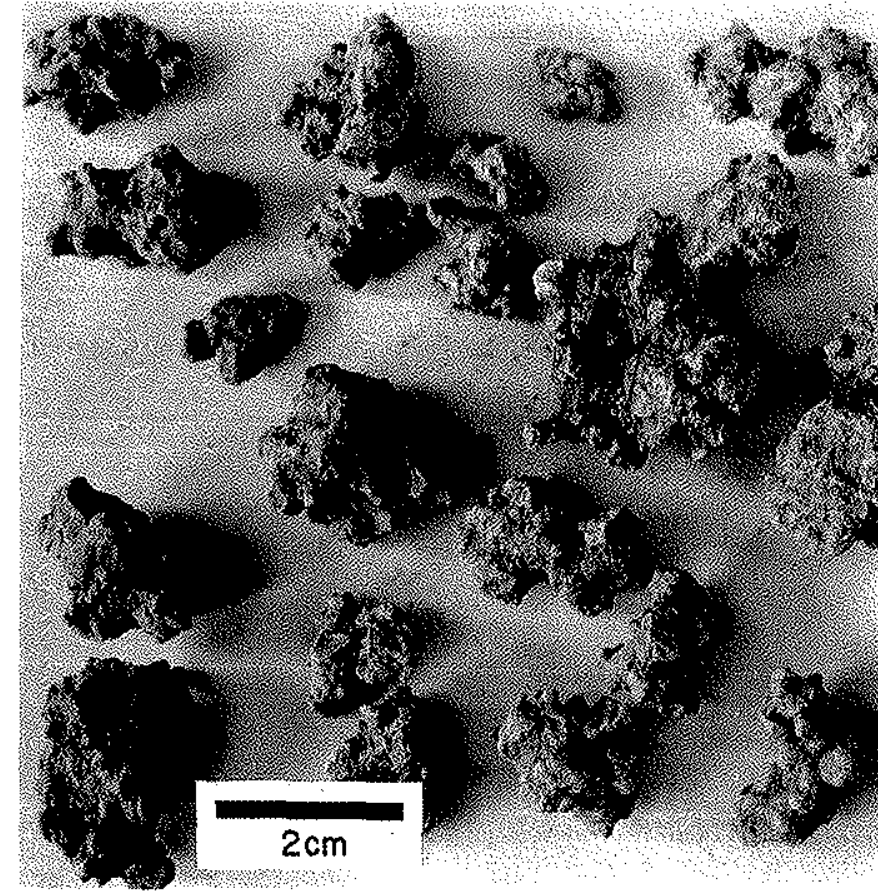

Foto 8-Agregados gibbsíticos provenientes da cimentaşão $e$ da substituição por gibbsita porcelanada do cascalho ferruginoso do topo da seqüência bauxítica. BR-010, quilometro 1603

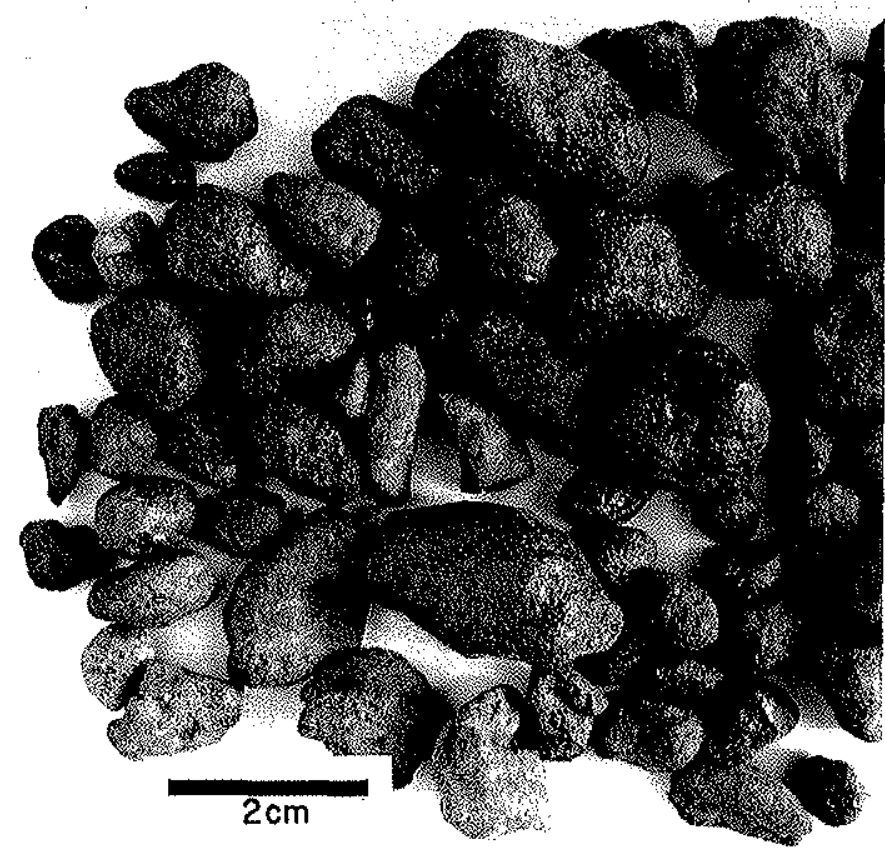

Foto 9-Pseudopisólitos ferruginosos do topo da seqüência laterítica. Area de Açailândia

\section{BIBLIOGRAFIA}

ALMARAZ, J.S. - 1977 - Aspectos Geoquímicos e Ambientais dos Calcário da Formaçăo Pirabas - Estado do Pará. Tese de Doutorado, Univ. do Rio Grande do Sul, $272 \mathrm{pp}$. (Inédita).

ASSAD, R. - 1978 - Depósitos de bauxita na Amazônia. Anais XXX Cong. Bras. Geol. Recife 6: 2511-2519.

BARBOSA, G.V., BOAVENTURA, R.S. e PINTO, M.N. - 1973 - Geomorfologia da folha SB-23 Terezinha e parte da folha SB-24 Jaguaribe. Projeto RADAMBRASIL, Rio de Janeiro, 2: 11/1-11/24.

BARBOSA, G.V. e PINTO, M.N. - 1973 - Geomorfologia da folha SA-23 Såo Luis e parte da folha SA-24 Fortaleza. Projeto RADAMBRASIL, Rio de Janeiro, 3: $11 / 1-11 / 26$

BARDOSSY, G. $-1963-$ Die Entwickiung der Bauxitgeologie seit 1950. Symp Bauxites, Zagreb, 1: 31.50 .

BOULANGÉ, B. - 1973 - Influence de la geomorphologie sur la genèse des bauxites latéritiques. I.C.S.O.B.A., III Cong., Nice, 215-221.

CARROLL, D. - 1970 - Rock Weathering. New York, Plenum Press, $203 \mathrm{pp}$

DENNEN, W.H. e NORTON, H.A. - 1977 - Geology and geochemistry of bauxite deposits in the lower Amazon basin. Econ. Geol. 72: 82-89.

ERHART, H. - 1967 - La Genèse des Sols en tant que Phénomène Géologique. Paris, Masson, $177 \mathrm{pp}$.

ERHART, H, - 1973 - Itinéraires Géochi siques et Cycle de l'Aluminium. Genèse des Minerais d'Alumine, Lateritisition, Bauxitisation, Aluminification. Paris, Doin, $250 \mathrm{pp}$.

FERREIRA, C.S, VICALV1, M.A. e MACEDO, A.C.M. - 1981 - Notas sobre a sequêencia sedimentar ao sul do Rio Guamá, Estado do Pará. An. Acad. Brasil. Ciênc. 53: 208.209.

FRANCISCO, B.H.R., LOEWENSTEIN, P. e SILVA, O.F. - 1971 - Contri buição à geologia da folha de São Luís (SA-23) no Estado do Pará, lli. Estraligrafia, IV: Recursos minerais, Bol. Mus. Pa. E. Goeldi, n. ser. Geol. 17: $1-40$.

GREIG, E.W. - 1977 - Trombetas and other Amazon bauxites, Brazil. Soc. Mining Engineers AlME, $34 \mathrm{pp}$

GRUBB, P.L.C. - 1973 - High-level and low-level bauxitization: a criterion for classification. Miner, Sci-Engng. 5: 219.231.

GRUBB, P.L.C. - 1979 - Genesis of bauxite deposits in the lower Amazon basin and Guianas coastal plain. Econ. Geol. 74: 735-750.

HIERONYMUS, B. - 1973 - Etude minéralogique e géochimique des formations bauxitiques de l'ouest du Cameroun. Cah. ORSTOM, ser. Geol. V 97-112.

JEPSEN, K. e SCHELLMANN, W. - 1974 - Uber den Stoffbestand und die Bildungsbedingungen der Bauxitlagerstätte Weipa, Australien. Geol. Jb. D7: 19-106.

KLAMMER, G, - 1971 - Uber plio-plejstozane Terrassen und ihre Sedimente im unteren Amazonasgebiet. Z. Geomorph. 15: 62-106.
KOTSCHOUBEY, B. e TRUCKENBRODT, W. - 1980 - Gênese das bauxitas do distrito de Paragominas, Pará. Proposta de um modelo evolutivo. XXXI Cong. Bras. Geol. Resumos Bol. 2: 370, Camboriú.

KRONBERG, B.l., COUSTON, J.F., STILIANIDI FILHO, B., FYFE, W.S., NASH, R.A. e SUGDEN, D. - 1979 - Minor element geochemistry of the Paragominas bauxite, Brazil. Econ. Geol. 74: 1869.1875.

KROOK, L. - 1979 - Sedinent petrographical studies in Northern Suriname. Academisch Proefschrift, Vrije Universitejt Amsterdam, $154 \mathrm{pp}$.

LEVINSON, A.A. - 1974 - Introduction to Exploration Geochemistry. Wilmette, Iliinois, U.S.A., Applied Publishing L.td., 614 pp.

MILLOT; G. - 1970 - Geology of Clays. Paris, Masson, $429 \mathrm{pp}$

MOHR, E.C.J., VAN BAREN, F.A. e VAN SCHUYLENBORGH, J. - $1972-$ Tropical Soils. The Hague, Van Hoeve, $481 \mathrm{pp}$.

PEREL'MAN, A. - 1967 - Geochemistry of Epigenesis. New York, Plenum Press, $266 \mathrm{pp}$.

PERSONS, B.S. - 1970 - Laterite: Genesis, Location, Use. New York, Plenum Press, 103 pp.

REZENDE, W. e PAMPLONA, H.R.P. - 1970 - Estudo do desenvolvimento do Arco Ferrer-Urbano Santos. Bol. Tec. Petrobrás 13: 5-14.

SCHELlMANN, W. - 1974 - Kriterien für die Bildung, Prospektion und Bewertung lateritischer Silikatbauxite. Geol, $\mathrm{Jb}, \mathbf{\mathbf { D } 7}: 3-17$

SOMBROEK, W.G. - 1966 - Amazon soils. A reconnaissance of the soils of the Brazilian Amazon region. Wageningen, Holland, Centre for Agri. Publ. Do cument., $292 \mathrm{pp}$.

TENYAKOV, V.A. - 1973 - Geochemistry and mechanism of principal act of laterite process, 1.C.S.O.B.A., III Cong. Nice, 203-207 (em russo)

TOWSE, D. e VINSON, P.E. - 1959 - Lateritas aluminosas do Baixo Amazonas. Eng. Miner. Metalurgia 30: 133-135.

TRUCKENBRODT, W. e KOTSCHOUBEX, B. - 1980 - Gênese da Argila de Betterra, Terciário Superior, Região Amazônica. XXXI Cong. Bras. Geol. Resumos, Bol 2: 418, Camboriú.

VALETON, I. - 1972 - Bauxites. Amsterdam, Elsevier, 226 pp.

VALETON, 1. - 1980 - Relationship between paleo-environment and bauxite formation within laterites. Internat. Assoc. Sedimentologists, Ist. Europ. Mig. Bochum, Abstr., 134-135.

VITOVSKAYA, I.V. e NOVIKOV, V.M. - 1973 - Possible mechanism of aluminium accumulation in lateritic bauxites. I.C.S.O.B.A., IIl Cong., Nice, 195-201 (em russo)

WOLF, F.A.M. - 1972 - Bauxita na Amazônia. DNPM, 5\% Distrito Belém, re lat. interno, $46 \mathrm{pp}$.

WOLF, F.A.M. e SILYA, J.M.R. - 1973 - Provincia bauxitífera da Amazônia DNPM, 5\% Distrito Belém, relat. interno, $35 \mathrm{pp}$. 